2018 TheoLogica

An International Journal for Philosophy of Religion and Philosophical Theology

\title{
S.I. NEW THEMES IN ANALYTIC DOGMATIC THEOLOGY
}

DOI: https://doi.org/10.14428/thl.v2i1.1673

\section{Editorial: New Themes in Analytic Dogmatic Theology}

\author{
JAMES M. ARCADI \\ Fuller Theological Seminary \\ jamesarcadi@fuller.edu \\ JOSHUA R. FARRIS \\ Houston Baptist University \\ joshua.r.farris@gmail.com
}

Analytic theology (AT) is a particular approach to theology and the study of religion that engages with the tools, categories, and methodological concerns of analytic philosophy. As a named-entity, AT arrived on the academic scene with the 2009 Oxford University Press publication, Analytic Theology: New Essays in the Philosophy of Theology, edited by Oliver D. Crisp and Michael C. Rea. AT was arguably represented, prior to this publication, by the proto-analytic theologian Richard Swinburne in his noteworthy works on Christian doctrine (e.g. Providence and the Problem of Evil, Responsibility and Atonement, The Christian God, Faith and Reason, and The Resurrection of God Incarnate), as well as by other professional philosophers of religion such as Alvin Plantinga, Nicholas Wolterstorff, Richard Swinburne, William Alston, Eleonore Stump, Robert and Marilyn McCord Adams, Basil Mitchell, Keith Yandell, Paul Helm, and Stephen T. Davis, among others. These philosophers were addressing such topics as the coherence of theism, the rationality of religious belief, and the contributions of such philosophical theologians of the medieval past including Thomas Aquinas or William Ockham and those from modernity including René Descartes and Jonathan Edwards. Yet, the impetus for utilizing analytic philosophy to treat these topics emerged, not from the theological side of the conversation, but from the philosophical side. Anachronistically, then, the term "analytic theology" seems to aptly describe the work of these philosophers of religion.

Dogmatic, as a discipline in its own right, is theology done unabashedly from a foundation of authoritative sources such as Scripture(s), creeds, confessions, or dogmas of religious bodies. This mode of theologizing is sharply distinct from a form of natural theology that attempts to speak about God with a foundation independent of any of these authoritative sources. Despite the fact that the earliest attempts to bring analytic philosophical tools to the theological task were focused on natural theology or a mere theism, there seems to be no necessary reason why these tools cannot also aid in the dogmatic task as well. Related to the present special issue of TheoLogica, we (the editors) edited a special issue of the journal Open Theology (2017, vol 3, issue 1) entitled "Analytic 
Perspectives on Method and Authority in Theology." That issue was specifically focused on these types of methodological issues. The essays in this special issue of TheoLogica, in distinction, offer examples or demonstrations of analytic dogmatic theology at work.

The essays in this special issue specifically seek contemporary analytic philosophical instruments to hone, clarify, and exposit concepts that arise from reflection on these authoritative sources. Especially noteworthy in this issue are two essays by nonChristian scholars. Similar to the aforementioned point, whereas the AT conversation has largely been undertaken by those working within the Christian tradition, there is no necessary reason why these tools cannot also be put to the task of engaging with other religious traditions. In fact, a turn toward analytic dogmatic theology in its Christian form should, we hope, invite practitioners of Judaism, Islam, theistic Hinduism or other religions to work from their own authoritative sources, not having to reduce their dogmatic convictions to a mere theism. It might be outside the bounds of philosophy of religion to draw out the implications of, say, the Nicene Creed or the Talmud, but these sources are completely legitimate starting points for dogmaticians. Hence, Alex Sztuden's essay on Talmudic responses to the Euthyphro dilemma or Mohammad Saeedimehr's essay on the doctrine of Bada ', both operate from conceptual foundations within their own religious traditions. A similar posture is taken by R.T. Mullins and S.N. Nordby who place the deliverances of Scripture as important dogmatic authorities under which their reflections on the divine nature must stand. Jonathan Rutledge's essay traces out epistemic implications of the doctrine of the fall of humanity, a dogmatic mainstay in Christian theology. Furthermore, J.T. Turner and Christopher Woznicki investigate, with analytic philosophical tools, claims made in the Apostles' and Nicene Creeds concerning "the resurrection of the dead and the life of the world to come."

Hence, what we see in this issue of TheoLogica is another instance of the broadening out of AT into areas of religious experience outside the bounds of natural theology. This issue shows that analytic tools can be put to dogmatic service as the theologian works out the implications and connections of one's dogmatic conceptual infrastructure.

The Guest Editors (J. M. A., J. R. F.)

This issue is in a way a new start for our Journal. TheoLogica: An International Journal for Philosophy of Religion and Philosophical Theology is now published at the Catholic University of Louvain in cooperation with the Research Group in Theology and Religious Studies of the RSCS Institute. We wish to thank Bérangère Deprez, and Arnaud Willame for their support with this project.

The Editors (J.-B. G., I. L., A. P.) 